\title{
Lactic acid microbiota identification in water, raw milk, endogenous starter culture, and fresh Minas artisanal cheese from the Campo das Vertentes region of Brazil during the dry and rainy seasons
}

\author{
R. D. Castro, ${ }^{* 1}$ L. G. Oliveira, ${ }^{*}$ F. M. Sant'Anna, ${ }^{\prime}$ L. M. P. Luiz, ${ }^{*}$ S. H. C. Sandes, † C. I. F. Silva, ${ }^{*}$ A. M. Silva, $\ddagger$ \\ A. C. Nunes,† C. F. A. M. Penna, ${ }^{*}$ and M. R. Souza* \\ *Departamento de Tecnologia e Inspeção de Produtos de Origem Animal, and \\ †Departamento de Biologia Geral, Universidade Federal de Minas Gerais, Belo Horizonte, 31270-901, Brazil \\ ‡Departamento de Engenharia de Alimentos, Universidade Federal de São João del-Rei, Sete Lagoas, 35701-970, Brazil
}

\begin{abstract}
Minas artisanal cheese, produced in the Campo das Vertentes region of Brazil, is made from raw milk and endogenous starter cultures. Although this cheese is of great historical and socioeconomic importance, little information is available about its microbiological and physical-chemical qualities, or about its beneficial microbiota. This work was aimed at evaluating the qualities of the cheese and the components used for its production, comparing samples collected during the dry and rainy seasons. We also conducted molecular identification and isolated 50 samples of lactic acid bacteria from cheese $(\mathrm{n}=21)$, water $(\mathrm{n}=3)$, raw milk ( $\mathrm{n}$ $=9$ ), and endogenous starter culture $(\mathrm{n}=17)$. The microbiological quality of the cheese, water, raw milk, and endogenous starter culture was lower during the rainy period, given the higher counts of coagulase-positive Staphylococcus and total and thermotolerant coliforms. Enterococcus faecalis was the lactic acid bacteria isolated most frequently $(42.86 \%)$ in cheese samples, followed by Lactococcus lactis $(28.57 \%)$ and Lactobacillus plantarum (14.29\%). Lactobacillus brevis (5.88\%), Enterococcus pseudoavium (5.88\%), Enterococcus durans (5.88\%), and Aerococcus viridans (5.88\%) were isolated from endogenous starter cultures and are described for the first time in the literature. The lactic acid bacteria identified in the analyzed cheeses may inhibit undesirable microbiota and contribute to the safety and flavor of the cheese, but this needs to be evaluated in future research.
\end{abstract}

Key words: artisanal cheese, 16S rRNA sequencing, cheese composition, microbiology

Received October 29, 2015.

Accepted May 1, 2016.

${ }^{1}$ Corresponding author: renatadiascastro@yahoo.com.br

\section{INTRODUCTION}

The state of Minas Gerais is the greatest milk producer in Brazil, producing about 8.7 billion L per year, or $27.1 \%$ of the national total (Instituto Brasileiro de Geografia e Estatística, 2011). Minas Gerais is also Brazil's largest producer of cheese, including the Minas artisanal variety, which is recognized throughout the country (Martins et al., 2015). Minas artisanal cheesemaking is has been designated as an intangible cultural heritage (Instituto Do Patrimônio Histórico e Artístico Nacional, 2008), and Minas cheeses are produced only on farms from certified regions using raw milk, obtained from zoonoses-free herds, with added endogenous starter cultures and clotting agents, under good manufacturing practices. The endogenous starter culture comes from the whey drained from previously made cheeses, which is collected and used for cheesemaking on the next day.

Some aspects of Minas artisanal cheese productionincluding turning cheeses during brining and ripening, as well as rinsing - are critical to its quality but mean that the product is frequently manipulated. These steps must be carried out with caution to avoid bacterial contamination. Moreover, cheeses must be ripened to reach quality standards that make them safe to consume, but the majority of Minas artisanal cheeses are sold fresh and in some cases produced without starter endogenous cultures.

Lactic acid bacteria (LAB), originating mainly from raw milk and endogenous starter cultures, are essential to the ripening and the safety of Minas artisanal cheese. They synthesize many antimicrobial compounds, including organic acids (mainly lactic acid), hydrogen peroxide, and bacteriocins, which may inhibit spoiling and the growth of pathogenic bacteria. They also contribute to cheese flavor and may play a probiotic role.

In 2009, the Campo das Vertentes region of Minas Gerais received official identification as a Minas artisanal cheese producer (Minas Gerais, 2009), taking 
into consideration edaphoclimatic, agroecological, and sociocultural studies. Since then, a growing number of producers have sought certification of their cheeses from the state inspection service.

Although there is a long tradition of Minas artisanal cheese production from the Campo das Vertentes region, little information is available about the microbiological and physical-chemical qualities of the cheeses; the raw milk and endogenous starter cultures; or the LAB present in the cheeses. The present work was aimed at evaluating the qualities of fresh Minas artisanal cheese from Campo das Vertentes, comparing samples collected in the dry and rainy seasons. The study also aimed at identifying the LAB present in samples of cheese, water, raw milk, and endogenous starter culture, using molecular approaches.

\section{MATERIALS AND METHODS}

\section{Sampling}

We selected 6 Minas artisanal cheese producers who were not certified by the state inspection service from Campo das Vertentes because they used endogenous starter culture in their cheesemaking. We collected fresh cheeses sampled on the day after production, raw milk, endogenous starter culture, and water used for cheesemaking at the farms in December 2013 and April 2014 (rainy season) and in July 2014 (dry season). We collected 12 samples of cheeses and their components during the experimental period.

\section{Microbiological Analyses}

All microbiological analyses were carried out following the recommendations of American Public Health Association (Andrews et al., 2001; Kornacki and Johnson, 2001; Lancette and Tatini, 2001; Morton, 2001), except for mold and yeast counts, which were performed according to the Bacteriological Analytical Manual (Tournas et al., 2001).

Water samples were analyzed for the most probable number (MPN) of total and thermotolerant coliforms at $30^{\circ} \mathrm{C}$ and $45^{\circ} \mathrm{C}$, respectively (American Public Health Association, 2005), and for aerobic mesophilic microorganism counts (Morton, 2001). Samples of raw milk, endogenous starter culture, and fresh cheese were analyzed for the MPN of total and thermotolerant coliforms (Kornacki and Johnson, 2001); counts of Staphylococcus spp., coagulase-positive Staphylococcus (Lancette and Tatini, 2001), and molds and yeasts (Tournas et al., 2001); and the presence of Salmonella spp. (Andrews et al., 2001).

\section{Physicochemical Analyses}

Water samples were analyzed in triplicate for hardness, $\mathrm{pH}$, and residual chlorine (American Public Health Association, 2005).

Raw milk samples were analyzed for percentage of fat, protein, lactose, and total solids using the Bentley CombiSystem 2300 (Bentley Instruments Inc., Chaska, $\mathrm{MN}$ ) and based on the absorption of infrared wavelengths (IDF, 2000). Using the same equipment, SCC was determined by flow cytometry (IDF, 1995). Total bacterial count was also determined by flow cytometry (Suhren and Walte, 2000) using the BactoCount IBC (Bentley Instruments Inc.).

Fresh cheese samples were analyzed for percentage of total solids and moisture using the gravidity method (IDF, 1982); fat content using the Gerber-Van Gulik butyrometer method (IDF, 2008); nitrogen compounds using the Kjeldahl method (IDF, 1993); pH (British Standards, 1976); and titratable acidity (Merck, 1993). Total protein content was obtained by multiplying total nitrogen by 6.38 . All physical-chemical analyses were carried out in triplicate.

\section{Molecular Identification of Lactic Acid Bacteria}

The molecular identification of LAB was carried out from material obtained from all kinds of collected samples. Decimal dilutions were prepared, and 0.1 $\mathrm{mL}$ of each sample was spread on the surface of MRS and M17 media (both from Difco Laboratories Inc., Detroit, MI). Plates were incubated under aerobiosis at $37^{\circ} \mathrm{C}$ for $48 \mathrm{~h}$ (IDF, 1988; Resende et al., 2011). Isolation, enumeration, gram staining, catalase testing, and purification of LAB were performed according to MacFaddin (1980) and IDF (1988). After growth, colonies were enumerated and distinct gram-positive and catalase-negative morphologic types were submitted to molecular identification.

For DNA extraction, the selected bacteria were grown in the same isolation broth under the same conditions of time and temperature, followed by centrifugation for 15 min at $4,000 \times g$ at room temperature. Pellets were treated with $5 \mathrm{M}$ lithium chloride and incubated at room temperature under agitation for $90 \mathrm{~min}$. Then, they were centrifuged and suspended in $1 \mathrm{~mL}$ of a protoplasts buffer $(50 \mathrm{~m} M$ Tris $\mathrm{HCl}$; $\mathrm{pH} 8.0,10 \mathrm{mM}$ EDTA, $10 \mathrm{mg} / \mathrm{mL}$ of lysozyme, and $25 \mathrm{~m} M$ sucrose) and incubated at $37^{\circ} \mathrm{C}$ under agitation for $1 \mathrm{~h}$ (Sandes et al., 2014). The DNA was obtained using the Kit Wizard SV Genomic DNA Purification System (Promega Corp., Madison, WI), according to manufacturer instructions. 
The DNA samples were submitted to PCR using primers 27F (5'-AGAGTTTGATCCTGGCTCAG-3') and 1492R (5'-GGTTACCTTGTTACGACTT-3'), as described by Lane (1991). Amplification was performed as follows, according to Moreira et al. (2005): 1 cycle of $95^{\circ} \mathrm{C}$ for $2 \mathrm{~min} ; 35$ cycles of $95^{\circ} \mathrm{C}$ for $30 \mathrm{sec}, 55^{\circ} \mathrm{C}$ for $1 \mathrm{~min}$, and $72^{\circ} \mathrm{C}$ for $1 \mathrm{~min}$; and 1 last cycle of $72^{\circ} \mathrm{C}$ for $5 \mathrm{~min}$. The obtained PCR products were sequenced using the Sanger method with the MegaBACE 1000 automated sequencer (GE Healthcare, Piscataway, NJ), according to Reysenbach et al. (2000). Results were submitted to the BLAST algorithm on the National Center of Biotechnology Information website (http:// blast.ncbi.nlm.nih.gov/Blast.cgi).

We differentiated between Lactobacillus (Lb.) plantarum, $L b$. paraplantarum, and $L b$. pentosus using multiplex-PCR with specific primers targeted at the amplification of the recA gene, according to Torriani et al. (2001). We differentiated between $L b$. casei, $L b$. paracasei, and $L b$. rhamnosus using PCR with primers specific to each of the species and targeting the V1 region of the $16 S$ rRNA gene, as described by Ward and Timmins (1999).

\section{Statistical Analyses}

All experimental data are reported as means, CV, and minimum and maximum values. Normality was confirmed using the Shapiro Wilk method. All statistical analyses were processed using the 2008 version of InfoStat/Professional (Grupo InfoStat, Facultad de Ciencias Agrarias, Universidad Nacional de Córdoba, Córdoba, Argentina). Nonparametric variables were analyzed using the Friedman test. Parametric variables were analyzed using ANOVA, and significance was assessed using Fisher's least significant difference (LSD) test. Significance was declared at $P<0.05$.

\section{RESULTS AND DISCUSSION}

\section{Microbiological and Physicochemical Quality of Water}

Water collected from cheesemaking facilities during the dry and rainy seasons did not reach the potability standard of the absence of total and thermotolerant coliforms (WHO, 2011a). It was considered inadequate for cheesemaking (Table 1).

The mean count of mesophilic aerobic microorganisms in the dry season was lower than in the rainy season $(P<0.05$; Table 1$)$. Contamination in the latter may have been associated with higher temperatures and humidity (Instituto Nacional de Meteorologia,

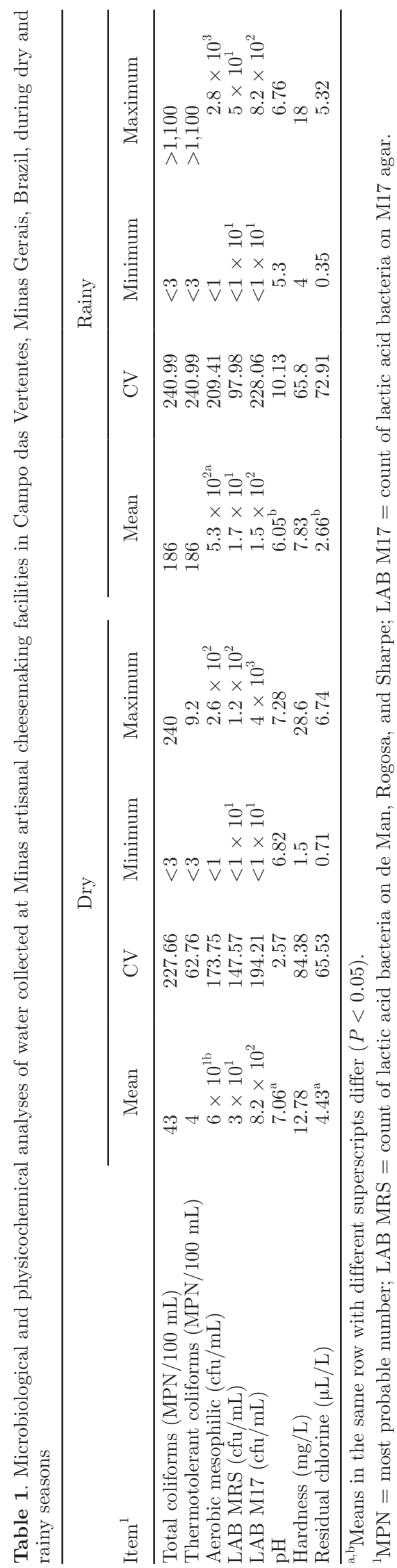


2013a,b, 2014a,b) data. Such climatic factors enhance the growth of bacteria, even in water samples.

Water $\mathrm{pH}$ mean values in the rainy and dry seasons were different, at 6.05 and 7.06 (Table 1), respectively $(P<0.05)$, but both were adequate for cheesemaking, which requires a $\mathrm{pH}$ of 6.0 to 9.5 (Brasil, 2012). These findings favored the efficiency of the cleaning and disinfection procedures at the cheesemaking facilities, and may contribute to a longer lifespan for the cheesemaking equipment.

The Brazilian Ministry of Health has determined that the water for human consumption must have a maximum hardness of $500 \mathrm{mg} / \mathrm{L}$ of calcium carbonate (Brasil, 2012). In both seasons, water quality met that standard (Table 1); in fact, water samples collected in both seasons were very soft (WHO, 2011b).

Residual chlorine concentration in water samples was higher in the dry season than in the rainy season $(P<$ 0.05; Table 1). This difference may have been because most farmers chlorinated water manually directly at the reservoir without taking water flow rate into account. Adding the same amount of chlorine regardless of season would increase the chlorine concentration in the dry season because water flow rates are lower than in the rainy season. High chlorine concentrations in the dry season are undesirable in food processing, causing abnormal flavors and leading to possible consumer health concerns because of the toxic effects of excessive chlorine intake.

On the other hand, the minimum values of chorine recorded in water samples in the dry and rainy seasons, 0.75 and $0.35 \mathrm{ppm}$ (Table 1), respectively, highlighted the inefficiency of chlorination in some of the studied farms and raised concerns about cleaning and disinfection procedures (WHO, 2011a), possibly compromising cheese quality.

\section{Microbiological Quality of Endogenous Starter Cultures}

Endogenous starter cultures showed high counts of all microorganisms of interest, in line with results from previously published papers (Borelli et al., 2006; Lima et al., 2009; Dores et al., 2013). Endogenous starter cultures with high MPN of coliforms and high counts of Staphylococcus spp., molds, and yeasts (Table 2) represent a source of contamination. On the other hand, high LAB counts may play an intrinsic protective role against the undesirable microorganisms, as well as contributing to the sensory profile of the cheese.

The higher mean MPN of thermotolerant coliforms in endogenous starter cultures samples during the rainy season $(P<0.05$; Table 2$)$ may be explained by climatic conditions, which were favorable to microbial

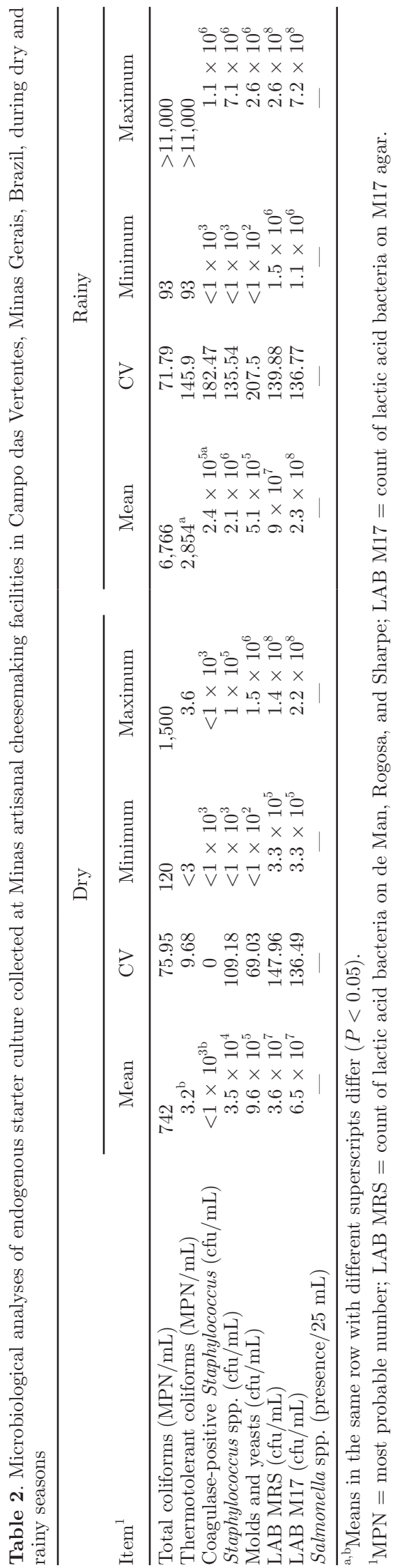

Journal of Dairy Science Vol. 99 No. 8, 2016 
growth. Endogenous starter cultures are kept without cooling until they are used in the next day's cheesemaking. Deficiencies in the cleaning and disinfection of cheesemaking utensils may also have played a role. Once they are present in high numbers, as seen in Table 2 , these bacteria quickly cause the food to deteriorate along with the presence of gases, as lactose is metabolized to carbon dioxide in the fermentation process. Furthermore, some microorganisms in this group have pathogenic potential (Jay et al., 2005).

We observed no differences in MPN of total coliforms during the dry and rainy seasons (Table 2). Borelli et al. (2006) have reported that the MPN of total coliforms varied from 93 to $>1,100 / \mathrm{mL}$ in endogenous starter cultures of Minas artisanal cheeses produced in the Serra da Canastra region.

We observed higher counts of coagulase-positive Staphylococcus in endogenous starter cultures collected in the rainy season $(P<0.05$; Table 2$)$. This may be for reasons similar to those for the high MPN of coliform bacteria described above, associated with the manipulation of endogenous starter culture, because 30 to $50 \%$ of humans are asymptomatic carriers of coagulase-positive Staphylococcus (Stamford et al., 2006). Another factor may have been the high incidence of mastitis in Brazilian dairy herds (Costa et al., 2012).

Counts of molds and yeasts in endogenous starter cultures from the present study were similar to those recorded using the same materials and methods for Minas artisanal cheese production in Serra do Salitre; values ranged from $3 \times 10^{1}$ to $2.7 \times 10^{5} \mathrm{cfu} / \mathrm{mL}$ (Lima et al., 2009).

\section{Microbiological and Physicochemical Quality of Raw Milk}

Milk fat percent content may vary from 2 to 4 percentage points. Factors such as genetics, season, ratio of roughage to concentrate, fiber intake, type of concentrate fed, and fat and additive feeding may influence fat content (Lerch et al., 2015). The lower mean fat content recorded in samples of raw milk collected during the dry season $(P<0.05$; Table 3$)$ may be explained by cows' higher concentrate intake because roughage is less available than in the rainy season. A diet higher in concentrate increases acid production in the rumen, lowering the $\mathrm{pH}$ and compromising fiber digestion, so that the proportion of acetic acid is decreased and the proportion of propionic acid is increased. Acetic acid is a main precursor for milk fat, so its decrease is directly related to lower fat content in milk (Guo et al., 2013).

Protein and lactose content in milk are less influenced by extrinsic factors (Wattiaux, 2012), and we also observed an absence of variation in these param-

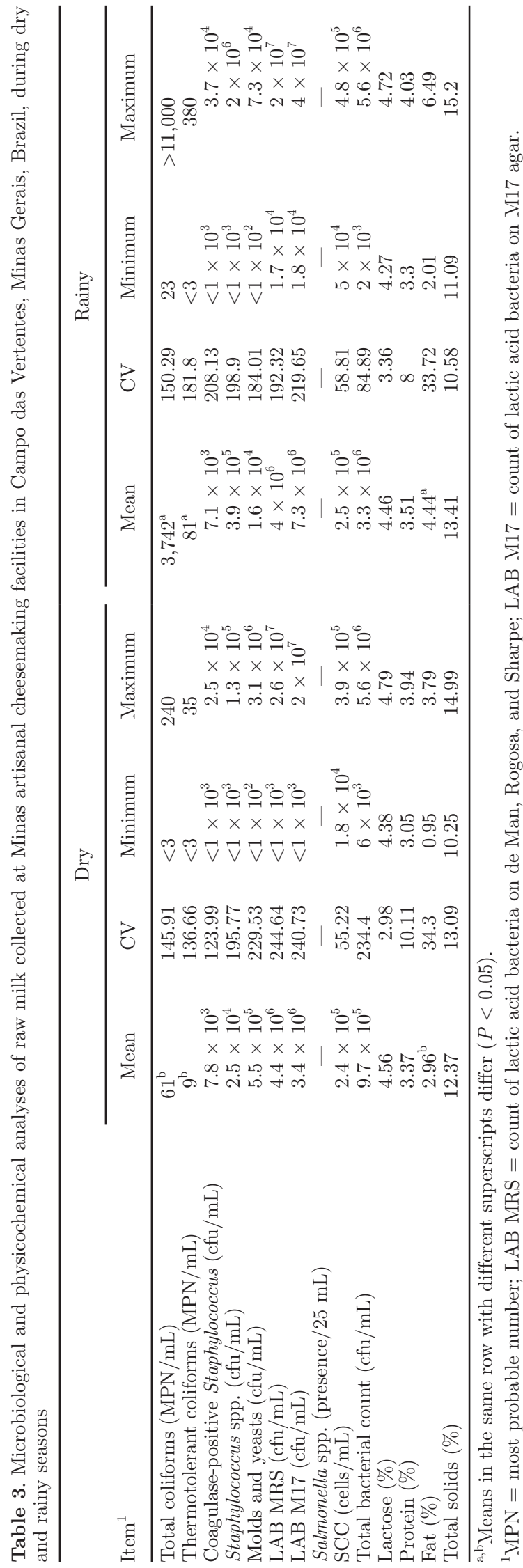


eters, based on mean values from the different seasons and a low CV (Table 3). Milk TS content is normally influenced by the factors that alter fat content, and we observed this trend (Table 3 ): TS were numerically higher in the dry season, but this difference was not significant.

Another parameter that influences milk quality for cheesemaking is total bacterial count. We did not observe a statistical difference between seasons for milk total bacterial count. Souza et al. (2003) also observed no seasonal difference in mean total bacterial count of the raw milk used for Serrano artisanal cheesemaking. The mean total bacterial count was $1.2 \times 10^{6} \mathrm{cfu} / \mathrm{mL}$ in the summer and $5 \times 10^{5} \mathrm{cfu} / \mathrm{mL}$ in the winter.

We observed higher counts of total and thermotolerant coliforms and high CV in raw milk sampled during the rainy season $(P<0.05$; Table 3$)$, similar to what was described by Martins et al. (2015) in the Serro region. These findings were likely caused by environmental conditions that favored the growth of that group of bacteria. Inadequate cleaning and disinfection of the milking equipment and of the environment in which the animals were raised may also have been a factor. As well, contamination during and after milking, during milk transportation to the cheesemaking facility, and inside the facility, may have increased coliform MPN in raw milk. Environmental mastitis in dairy cattle also could explain the increase in coliform MPN, which are generally not associated with increased SCC in bulk tank milk, as observed in the present study (Table 3).

We observed the application of measures to reduce the presence of Staphylococcus spp. in milk at some of the farms, such as pre- and postdipping of the teat, milking management (order of animals for milking), dry cow therapy, and culling of chronically infected animals, but Staphylococcus counts were high in both seasons. It is evident that another reservoir of the bacterium existed in the milking production system, allowing for new infections, such as the cow itself (skin and teat lesions), the milkers (contaminated hands), or the milking equipment (biofilms).

Counts of LAB in raw milk were high in both seasons (Table 3). This is desirable for Minas artisanal cheesemaking, because LAB are responsible for flavor, and likely for inhibiting pathogens. In a study of raw milk used for production of Zlatar, an artisanal Slovakian cheese, LAB reached mean values similar to those recorded in the present study (Veljovic et al., 2007).

Counts of molds and yeasts in the present study were opposite to those observed in raw milk used for Casín artisanal cheese from the Asturias region of Spain; in that study, no molds and yeasts were found (Alegría et al., 2009).

\section{Microbiological and Physicochemical Quality of Fresh Minas Artisanal Cheese}

Mean total and thermotolerant coliform counts were higher in cheeses collected in the rainy season than in the dry season $(P<0.05$; Table 4$)$. This result was expected, because higher counts of those bacteria were found in both raw milk and endogenous starter cultures during the rainy season (Tables 2 and 3). High MPN of total coliforms are responsible for cheese deterioration, causing early blowing. Thermotolerant coliforms cause the cheese to deteriorate and include pathogenic samples that are harmful to humans and other animals (Jay et al., 2005).

The mean count of coagulase-positive Staphylococcus was higher in cheeses collected during the rainy season than in those collected during the dry season $(P<0.05$; Table 4$)$. Most of that difference may be attributed to the use of an endogenous starter culture that was contaminated with the same microorganism in the same season $(P<0.05$; Table 2$)$. The presence of this bacterium in counts higher than $10^{4} \mathrm{cfu} / \mathrm{g}$ in all analyzed cheeses from both seasons is alarming; it may produce enterotoxins and cause food poisoning (Johler et al., 2015).

The mean count for LAB on M17 agar was higher in cheeses sampled in the dry season than in the rainy season $(P<0.05$; Table 4$)$. This may have been because a higher amount of starter endogenous culture was used for cheesemaking in the dry season. Most cheese producers report using this procedure to maintain the milk clotting process when room temperature is lower. Another explanation could be the lower coliform bacteria counts for the same period $(P<0.05$; Table 4$)$; coliform bacteria can ferment lactose and compete with LAB for nutrients.

The high mean counts of molds and yeasts recorded in cheeses (Table 4) point to inadequate disinfection of the utensils used for cheesemaking and the use of contaminated raw material. These microorganisms are undesirable because they may synthesize mycotoxins, which may be involved in food poisoning (Jay et al., 2005).

We detected no Salmonella spp. in the analyzed cheeses. The absence of that bacterium in the raw materials used for cheesemaking (Tables 2 and 3), care in cheese processing and handling, and preventive methods used to avoid cross-contamination, as well as possible inhibition by LAB, may explain these results.

We were unable to verify any statistical difference in mean moisture content and TS in the cheeses sampled in either season. This was because of the short time cheeses stayed on the farms under the environmental 


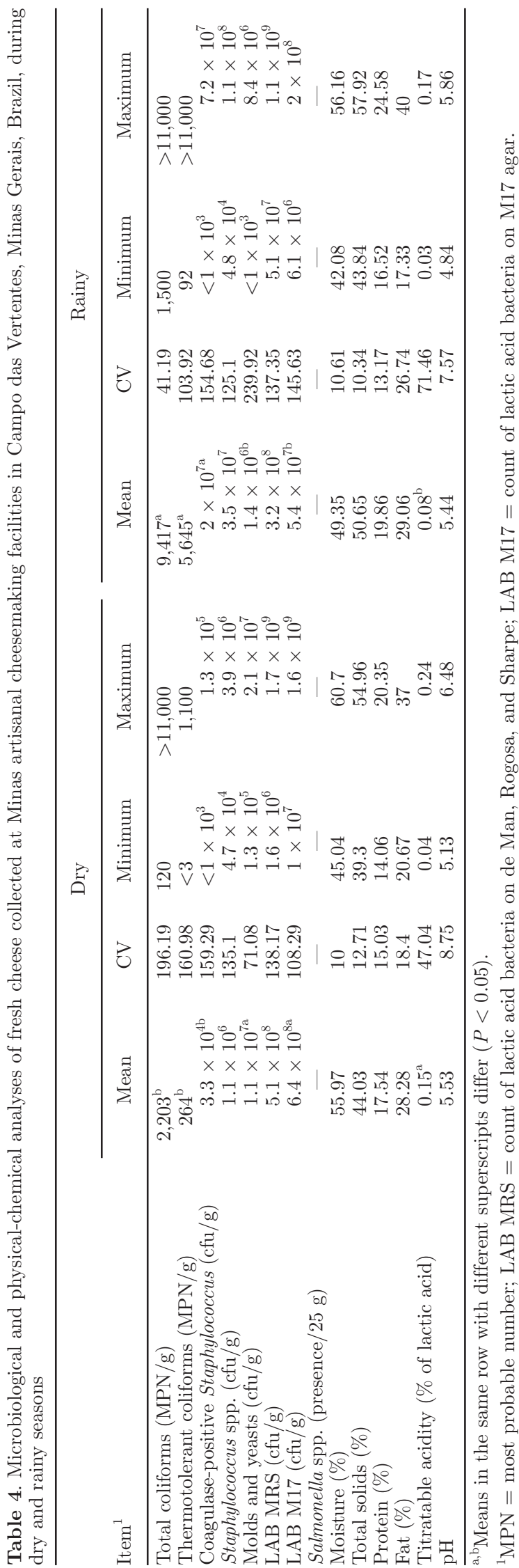

conditions: samples were collected on the day after production. Season did not influence moisture content, demonstrating that cheesemaking was performed in a similar way on the different farms, even in different seasons. This finding may be corroborated by low CV values for moisture reported in the dry and rainy seasons (Table 4).

Protein content results similar to those of the present study have been reported for Minas artisanal cheeses produced in the Serro, Serra da Canastra, and Cerrado regions, showing mean values of $14.08,18.51$, and $14.55 \%$, respectively (Oliveira et al., 2013). In the present study, the mean milk fat percentage was higher in raw milk sampled during the rainy season $(P<0.05$; Table 2), but the mean milk fat percentage was not statistically different in cheeses in the different seasons (Table 4). Cheese fat content depends on milk fat content, but it may be influenced by other factors, such as the moisture content of the cheese, the time of aging, and the presence of lipolytic microorganisms.

The mean titratable acidity of the cheeses produced in the dry season was higher than those recorded in the rainy season $(P<0.05$; Table 4$)$, similar to results described by Martins et al. (2015). This finding may be explained by the higher LAB counts in the dry season $(P<0.05)$. During lactose formation, LAB produce lactic acid as a major metabolic compound. The higher titratable acidity in cheese partially justifies the lower counts $(P<0.05)$ of coagulase-positive Staphylococcus and total and thermotolerant coliforms, as well as the absence of Salmonella spp. in the cheese samples from the dry season. Higher acidity favors the development of molds and yeasts (Jay et al., 2005), and these occurred in higher mean counts in samples from the dry season $(P<0.05$; Table 4$)$. However, we did not observe statistical differences between the mean $\mathrm{pH}$ values of the analyzed cheeses (Table 4), corroborating the lack of direct relation between titratable acidity and $\mathrm{pH}$ (Scott, 2002).

\section{Molecular Identification of LAB in Water, Endogenous Starter Cultures, Raw Milk, and Fresh Minas Artisanal Cheeses}

We identified 50 samples of LAB at the molecular level by the amplification and sequencing of the $16 \mathrm{~S}$ rRNA gene (fragments of approximately 1,500 bp) with a similarity threshold higher than $97 \%$. We isolated 3 samples from water (6\%), 9 from raw milk (18\%), 17 from endogenous starter culture $(34 \%)$, and 21 from fresh cheese ( $42 \%$; Table 5$)$.

From the identified samples, Enterococcus faecalis was the LAB most frequently isolated from raw milk $(66.67 \%)$, endogenous starter culture $(41.18 \%)$, and 
fresh cheeses $(42.86 \%)$ during the dry or rainy seasons. Similar results were recorded by Andrighetto et al. (2001) for Asiago, Montasio, Monte Veronese, and Fontina, all artisanal cheeses produced in Italy.

Enterococcus durans has been described in milk and dairy products (Ercan et al., 2014), but we isolated it from the endogenous starter culture, along with Enterococcus pseudoavium. These are the first reports in the literature for both of these LAB.

Generally, the presence of Enterococcus spp. in foods is of concern, because some types may be pathogenic to human, causing cardiovascular, urinary tract, or nervous system infections (Murray, 1990). A lack of knowledge about the virulence and transmission of resistance to important antimicrobials such as vancomycin inhibits the use of Enterococcus spp. in the food industry, especially if the focus is the elaboration of foods carrying probiotics (Hammad et al., 2015). On the other hand, the presence of these bacteria in cheeses is related to flavoring compounds that contribute to sensory properties (Kirmaci et al., 2014). Furthermore, Enterococcus spp. may be producers of bacteriocins, which are responsible for inhibiting the growth of pathogens such as Listeria monocytogenes and Staphylococcus aureus (Silvetti et al., 2014).

Lactococcus lactis was isolated from water (100\%), raw milk (11.11\%), and fresh cheeses $(28.57 \%)$ in the dry or rainy seasons. This bacterium is commonly used in cheese starter cultures and efficiently converts lactose to lactic acid. This LAB is dominant in fresh cheese, as identified in the present study, and it acts as a starter for the acidifying process. Its presence is reduced as the cheeses age (Fontán et al., 2001).

We isolated $L b$. plantarum only in the rainy season from raw milk $(22.22 \%)$, endogenous starter culture $(17.65 \%)$, and fresh cheeses (14.29\%). In a study carried out in the Serra da Canastra region, Lb. plantarum was the most isolated LAB in artisanal Minas cheese (Resende et al., 2011).

One sample of $L b$. rhamnosus $(4.76 \%)$ and another of $L c$. garvieae (4.76\%) were isolated from cheeses produced in the rainy season. Likewise, 1 sample of $L b$. paracasei $(5.88 \%)$ and another of Lb. brevis (5.88\%) were isolated from endogenous starter culture, also in the rainy season. At least 1 of these LAB species has been isolated in artisanal cheese or raw milk in different countries around the world (Coppola et al., 2006; Terzic-Vidojevic et al., 2009; Resende et al., 2011; Feutry et al., 2012). Although Lb. brevis has been isolated from samples of Minas artisanal cheeses, the literature contains no reports on its isolation from the endogenous starter culture used for cheesemaking. Lactobacillus rhamnosus, Lb. paracasei, and Lb. brevis are desirable for the elaboration of artisanal cheeses, either for the development of desirable sensory characteristics or as probiotics (Phillips et al., 2006; Zahedi et al., 2011).

Aerococcus viridans (5.88\%) was isolated from 1 sample of endogenous starter culture, only in the dry season. The literature contains no reports of that LAB in endogenous starter cultures used for the elaboration of artisanal cheeses. Although studies of its beneficial effects in foods are scarce, some reports point to its probiotic potential, but testing in vivo is needed (Hamed and Elattar, 2013; Ramirez-Chavarin et al., 2013).

Two samples of Leuconostoc mesenteroides (11.76\%) were isolated from endogenous starter cultures in the dry season. This bacterium has been found in endogenous starter cultures used for Mozzarella (Coppola et al., 1988) and for Minas artisanal production in the Serro region (Chaves et al., 1995). Leuconostoc mesenteroides has been used as a starter culture in cheeses to produce desirable sensory effects in the final product, some of which come from compounds formed during citrate metabolism, such as acetaldehyde, diacetyl, and acetoin. Furthermore, this LAB is responsible for the production of dextran from sucrose, as well as the synthesis of lipolytic and proteolytic enzymes that aid

Table 5. Molecular identification of lactic acid bacteria isolated from samples of water, raw milk, endogenous starter cultures, and fresh Minas artisanal cheeses collected at Minas artisanal cheesemaking facilities in Campo das Vertentes, Minas Gerais, Brazil, during dry and rainy seasons

\begin{tabular}{|c|c|c|c|}
\hline Microorganism & Dry & Rainy & Total \\
\hline \multicolumn{4}{|l|}{ Water } \\
\hline Lactococcus lactis & 3 & - & 3 \\
\hline Total & 3 & - & 3 \\
\hline \multicolumn{4}{|l|}{ Raw milk } \\
\hline Enterococcus faecalis & 6 & - & 6 \\
\hline Lactococcus lactis & 1 & - & 1 \\
\hline Lactobacillus plantarum & - & 2 & 2 \\
\hline Total & 7 & 2 & 9 \\
\hline \multicolumn{4}{|l|}{ Endogenous starter culture } \\
\hline Aerococcus viridans & 1 & - & 1 \\
\hline Lactobacillus plantarum & - & 3 & 3 \\
\hline Enterococcus faecalis & 4 & 3 & 7 \\
\hline Enterococcus pseudoavium & 1 & - & 1 \\
\hline Lactobacillus brevis & - & 1 & 1 \\
\hline Enterococcus durans & - & 1 & 1 \\
\hline Lactobacillus paracasei & - & 1 & 1 \\
\hline Leuconostoc mesenteroides & 2 & - & 2 \\
\hline Total & 8 & 9 & 17 \\
\hline \multicolumn{4}{|l|}{ Fresh Minas artisanal cheese } \\
\hline Lactococcus lactis & 5 & 1 & 6 \\
\hline Lactobacillus plantarum & - & 3 & 3 \\
\hline Enterococcus faecalis & 5 & 4 & 9 \\
\hline Lactococcus garvieae & - & 1 & 1 \\
\hline Enterococcus faecium & - & 1 & 1 \\
\hline Lactobacillus rhamnosus & - & 1 & 1 \\
\hline Total & 10 & 11 & 21 \\
\hline Overall total & 28 & 22 & 50 \\
\hline
\end{tabular}


in the development of flavor, texture and color ( $\mathrm{Ni}-$ eto Arribas et al., 2010). As well as its technological properties, some samples of Leuconostoc mesenteroides possess in vitro probiotic potential, including biliary salts deconjugation, self-aggregation, adhesion properties, $\beta$-galactosidase activity, and sensitivity to antimicrobials that are important for human and veterinary medicine (Abriouel et al., 2008; Paula et al., 2014).

\section{CONCLUSIONS}

The microbiological quality of the water, endogenous starter culture, raw milk, and fresh Minas artisanal cheese from the Campo das Vertentes region was influenced by season (dry or rainy). Fresh cheeses produced in the rainy season had worse microbiological quality, highlighting the importance of selling those cheeses only after aging. We isolated LAB from all studied samples, regardless of season. Enterococcus faecalis was isolated with higher frequency in samples of raw milk, endogenous starter culture, and fresh cheeses, followed by Lc. lactis and Lb. plantarum. Lactobacillus paracasei, Lb. brevis, Enterococcus pseudoavium, and Aerococcus viridans were isolated from endogenous starter culture, all of these described in the literature for the first time. The microbiological quality of the analyzed cheeses and components was compromised by the presence of undesirable microorganisms in both seasons. The LAB present in high counts may inhibit undesirable microbiota as well as contributing to flavor, but this must be evaluated in future research.

\section{ACKNOWLEDGMENTS}

The authors thank Empresa de Assistência Técnica e Extensão Rural do Estado de Minas Gerais (São João del-Rei, Brazil) and Instituto Mineiro de Agropecuária (Belo Horizonte, Brazil) for helping with contact with cheese producers and sampling collection. We also thank Fundação de Amparo a Pesquisa do Estado de Minas Gerais (Belo Horizonte, Brazil) for its financial support.

\section{REFERENCES}

Abriouel, H., A. Martín-Platero, M. Maqueda, E. Valdivia, and M. Martínez-Bueno. 2008. Biodiversity of the microbial community in a Spanish farmhouse cheese as revealed by culture-dependent and culture-independent methods. Int. J. Food Microbiol. 127:200-208.

Alegría, A., P. Alvarez-Martín, N. Sacristán, E. Fernández, S. Delgado, and B. Mayo. 2009. Diversity and evolution of the microbial populations during manufacture and ripening of Casín, a traditional Spanish, starter-free cheese made from cow's milk. Int. J. Food Microbiol. 136:44-51.

Andrews, W. H., R. S. Flowers, J. Silliker, and J. S. Bailey. 2001. Salmonella. Pages 357-376 in Compendium of Methods for the
Microbiological Examination of Foods. 4th ed. F. P. Downes and K. Ito, ed. Am. Public Health Assoc., Washington, DC.

Andrighetto, C., E. Knijff, A. Lombardi, S. Torriani, M. Vancanneyt, K. Kersters, J. Swings, and F. Dellaglio. 2001. Phenotypic and genetic diversity of enterococci isolated from Italian cheeses. J. Dairy Res. 68:303-316.

American Public Health Association. 2005. Standard Methods for the Examination of Water and Wastewater. 21st ed. A. D. Eaton, L. S. Clesceri, E. W. Rice, and A. E. Greenberg, ed. Am. Public Health Assoc., Washington, DC.

Borelli, B. M., E. G. Ferreira, I. C. A. Lacerda, D. A. Santos, L. S. Carmo, R. S. Dias, M. C. C. Silva, and C. A. Rosa. 2006. Enterotoxigenic Staphylococcus spp. and other microbial contaminants during production of Canastra cheese. Braz. J. Microbiol. $37: 545-550$.

Brasil, Ministério da Saúde, Gabinete do Ministro. 2012. Portaria n. 2.914 , de 12 de dezembro de 2011. Dispõe sobre procedimentos de controle e de vigilância da qualidade da água para consumo humano e seu padrão de potabilidade. Pages 43-49 in Diário Oficial da República Federativa do Brasil, Brasília, DF, Seção 1, 04 de janeiro de 2012. Ministério da Saúde, Brasilia, Brazil.

British Standards. 1976. Methods for chemical analysis of cheese. Determination of $\mathrm{pH}$ value. BS 770: Part 5. British Standards Institute, London, UK.

Chaves, A. H., A. J. R. Pinheiro, and M. A. Teixeira. 1995. Isolamento, caracterização e identificação de bactérias do gênero Leuconostoc. Rev. Inst. Laticínios Cândido Tostes 50:35-41.

Coppola, S., V. Fusco, R. Andolfi, M. Aponte, G. Blaiotta, D. Ercolini, and G. Moschetti. 2006. Evaluation of microbial diversity during the manufacture of Fior di Latte di Agerola, a traditional raw milk pasta-filata cheese of the Naples area. J. Dairy Res. 73:264-272.

Coppola, S., E. Parente, S. Dumontet, and A. La Peccerella. 1988. The microflora of natural whey cultures utilized as starters in the manufacture of Mozzarella cheese from water-buffalo milk. Lait 68:295-309.

Costa, G. M., L. V. Paiva, H. C. P. Figueiredo, A. R. Figueira, U. P. Pereira, and N. Silva. 2012. Population diversity of Staphylococcus aureus isolates from bovine mastitis in Brazilian dairy herds. Res. Vet. Sci. 93:733-735.

Dores, M. T., J. E. Nóbrega, and C. L. L. F. Ferreira. 2013. Room temperature aging to guarantee microbiological safety of Brazilian artisan Canastra cheese. Food Sci. Technol. (Campinas) 33:180-185.

Ercan, D., F. Korel, and H. Orşahin. 2014. Microbiological quality of artisanal Sepet cheese. Int. J. Dairy Technol. 67:384-393.

Feutry, F., M. Oneca, F. Berthier, and P. Torre. 2012. Biodiversity and growth dynamics of lactic acid bacteria in artisanal PDO OssauIraty cheeses made from raw ewe's milk with different starters. Food Microbiol. 29:33-42.

Fontán, M. C. G., I. Franco, B. Prieto, M. E. Tornadijo, and J. Carballo. 2001. Microbiological changes in 'San Simón' cheese throughout ripening and its relationship with physico-chemical parameters. Food Microbiol. 18:25-33.

Guo, Y., L. Wang, Y. Zou, X. Xu, S. Li, and Z. Cao. 2013. Changes in ruminal fermentation, milk performance and milk fatty acid profile in dairy cows with subacute ruminal acidosis and its regulation with pelleted beet pulp. Arch. Anim. Nutr. 67:433-447.

Hamed, E., and A. Elattar. 2013. Identification and some probiotic potential of lactic acid bacteria isolated from Egyptian camels milk. Life Sci. 10:1952-1961.

Hammad, A. M., H. A. Hassan, and T. Shimamoto. 2015. Prevalence, antibiotic resistance and virulence of Enterococcus spp. in Egyptian fresh raw milk cheese. Food Contr. 50:815-820.

Instituto Brasileiro de Geografia e Estatística. 2011. Produção da Pecuária Municipal. Instituto Brasileiro de Geografia e Estatística, Rio de Janeiro, Brazil.

IDF (International Dairy Federation). 1982. Cheese and processed cheese: Determination of total solids content. IDF Standard 4A. Int. Dairy Fed., Brussels, Belgium.

IDF (International Dairy Federation). 1988. Yogurt: Enumeration of characteristic microorganisms colony count technique at $37^{\circ} \mathrm{C}$. IDF Standard 117A. Int. Dairy Fed., Brussels, Belgium. 
IDF (International Dairy Federation). 1993. Milk: Determination of nitrogen content. IDF Standard 20B. Int. Dairy Fed., Brussels, Belgium.

IDF (International Dairy Federation). 1995. Milk: Enumeration of somatic cells. IDF Standard 148A. Int. Dairy Fed., Brussels, Belgium.

IDF (International Dairy Federation). 2000. Whole milk: Determination of milkfat, protein and lactose contend. Guidance on the operation of mid-infrared instruments. IDF Standard 141C. Int. Dairy Fed., Brussels, Belgium.

IDF (International Dairy Federation). 2008. Cheese: Determination of fat content. Butyrometer for Van Gulik method. ISO Standard 3432. IDF Standard 221. Int. Dairy Fed., Brussels, Belgium.

Instituto Nacional de Meteorologia. 2013a. Chuva acumulada mensal $\times \mathrm{n}^{\circ}$ de dias com chuva-Barbacena (MG) - para o ano: 2013. Accessed Dec. 10, 2014. http://www.inmet.gov.br/portal/index. php? $\mathrm{r}=$ tempo/graficos.

Instituto Nacional de Meteorologia. 2013b. Temperaturas diárias (máxima, média, mínima) —Estação Barbacena (MG) 12/2013. Accessed Dec. 10, 2014. http://www.inmet.gov.br/portal/index. php? $\mathrm{r}=$ tempo/graficos.

Instituto Nacional de Meteorologia. 2014a. Chuva acumulada mensal $\mathrm{x} \mathrm{n}^{\mathrm{0}}$ de dias com chuva-Barbacena (MG) - para o ano: 2014 até 22/12/2014. Accessed Dec. 10, 2014. http://www.inmet.gov.br/ portal/index.php? $\mathrm{r}=$ tempo/graficos.

Instituto Nacional de Meteorologia. 2014b. Temperaturas diárias (máxima, média, mínima) —Estação Barbacena (MG) 04/2014. Accessed Dec. 10, 2014. http://www.inmet.gov.br/portal/index. $\mathrm{php}$ ? $\mathrm{r}=$ tempo/graficos

Instituto Do Patrimônio Histórico e Artístico Nacional. 2008. Livro de Registro de Saberes. Brasília, DF. Accessed Dec. 29, 2014. http:// www.iphan.gov.br/bcrE/pages/folProcessoRegistroE.jsf.

Jay, J. M., M. J. Loessner, and D. D. Golden. 2005. Modern Food Microbiology. 7th ed. Springer, New York, NY.

Johler, S., P. Giannini, M. Jermini, J. Hummerjohann, A. Baumgartner, and R. Stephan. 2015. Further evidence for staphylococcal food poisoning outbreaks caused by egc-encoded enterotoxins. Toxins (Basel) 7:997-1004

Kirmaci, H. A., A. A. Hayaloğlu, H. B. Özer, A. F. Atasoy, and H. Türkoğlu. 2014. Evolution of proteolysis in Urfa cheese made from ewe's milk by wild type starter culture systems. Small Rumin. Res. 119:120-129.

Kornacki, J. L., and J. L. Johnson. 2001. Enterobacteriaceae, coliforms and Escherichia coli as quality and safety indicators. Pages 69-80 in Compendium of Methods for the Microbiological Examination of Foods. 4th ed. F. P. Downes and K. Ito, ed. American Public Health Association, Washington, DC.

Lancette, G. A., and S. R. Tatini. 2001. Staphylococcus aureus. Pages 387-400 in Compendium of Methods for the Microbiological Examination of Foods. 4th ed. F. P. Downes and K. Ito, ed. American Public Health Association, Washington, DC.

Lane, D. J. 1991. 16S/23S rRNA sequencing. Pages 115-175 in Nucleic Acid Techniques in Bacterial Systematics. E. Stackebrandt and M. Goodfellow, ed. Wiley, Chichester, UK.

Lerch, S., J. A. Pires, C. Delavaud, K. J. Shingfield, D. Pomiès, B. Martin, Y. Chilliard, and A. Ferlay. 2015. Rapeseed or linseed in dairy cow diets over 2 consecutive lactations: effects on adipose fatty acid profile and carry-over effects on milk fat composition in subsequent early lactation. J. Dairy Sci. 98:1005-1018.

Lima, C. D. L. C., L. A. Lima, M. M. O. P. Cerqueira, E. G. Ferreira, and C. A. Rosa. 2009. Bactérias do acido láctico e leveduras associadas com o queijo-de-minas artesanal produzido na região da Serra do Salitre, Minas Gerais. Arq. Bras. Med. Vet. Zootec. 61:266-272.

MacFaddin, J. F. 1980. Biochemical Tests for Identification of Medical Bacteria. 2nd ed. Williams \& Wilkins, Baltimore, MD.

Martins, J. M., E. Galinari, N. J. Pimentel Filho, J. I. Ribeiro Jr, M. M. Furtado, and C. L. L. F. Ferreira. 2015. Determining the minimum ripening time of artisanal Minas cheese, a traditional Brazilian cheese. Braz. J. Microbiol. 46:219-230.
Merck. 1993. Reactivos, Diagnóstica, Productos Químicos 1992/93. Merck, Darmstadt, Germany.

Minas Gerais. 2009. Instituto Mineiro de Agropecuária. Portaria n. 1022 de 3 nov. 2009. Identifica a região de Campo das Vertentes. Accessed Dec. 5, 2014. http://imanet.ima.mg.gov.br/nova/legis/ portarias_pdf/1022.pdf.

Moreira, J. L. S., R. M. Mota, M. F. Horta, S. M. R. Teixeira, E. Neumann, J. R. Nicoli, and A. C. Nunes. 2005. Identification to the species level of Lactobacillus isolated in probiotic prospecting studies of human, animal or food origin by $16 \mathrm{~S}-23 \mathrm{~S}$ rRNA restriction profiling. BMC Microbiol. 5:15.

Morton, R. D. 2001. Aerobic plate count. Pages 63-67 in Compendium of Methods for the Microbiological Examination of Foods. 4th ed. F. P. Downes and K. Ito, ed. American Public Health Association, Washington, DC.

Murray, B. E. 1990. The life and times of the Enterococcus. Clin. Microbiol. Rev. 3:46-65.

Nieto-Arribas, P., S. Seseña, J. M. Poveda, L. Palop, and L. Cabezas. 2010. Genotypic and technological characterization of Leuconostoc isolates to be used as adjunct starters in Manchego cheese manufacture. Food Microbiol. 27:85-93.

Oliveira, D. F., M. A. C. Porto, C. E. C. Bravo, and I. B. Tonial. 2013. Caracterização físico-química de queijos Minas Artesanal produzidos em diferentes microrregiões de Minas Gerais. Rev. Bras. Econ. Domést. 24:185-196.

de Paula, A. T., A. B. Jeronymo-Ceneviva, L. F. Silva, S. D. Todorov, B. D. G. M. Franco, and A. L. B. Penna. 2014. Leuconostoc mesenteroides SJRP55: A potential probiotic strain isolated from Brazilian water buffalo mozzarella cheese. Probiotics Antimicrob. Proteins 6:186-197.

Phillips, M., K. Kailasapathy, and L. Tran. 2006. Viability of commercial probiotic cultures (L. acidophilus, Bifidobacterium sp., L casei, L. paracasei and L. rhamnosus) in cheddar cheese. Int. J. Food Microbiol. 108:276-280.

Ramirez-Chavarin, M. L., C. Wacher, C. A. Eslava-Campos, and M. L. Perez- Chabela. 2013. Probiotic potential of thermotolerant lactic acid bacteria strains isolated from cooked meat products. Int. Food Res. J. 20:991-1000.

Resende, M. F. S., H. H. S. Costa, E. H. P. Andrade, L. B. Acúrcio, A. F. Drummond, A. F. Cunha, A. C. Nunes, J. L. S. Moreira, C. F. A. M. Penna, and M. R. Souza. 2011. Queijo-de-minas artesanal da Serra da Canastra: Influência da altitude das queijarias nas populações de bactérias ácido-lácticas. Arq. Bras. Med. Vet. Zootec. 63:1532-1538.

Reysenbach, A. L., K. Longnecker, and J. Kirshtein. 2000. Novel bacterial and archael lineages from an in situ growth chamber deployed at a mid-Atlantic ridge hydrothermal vent. Appl. Environ. Microbiol. 66:3798-3806

Sandes, S. H., L. B. Alvin, B. C. Silva, D. F. Zanirati, L. R. Jung, J. R. Nicoli, E. Neumann, and A. C. Nunes. 2014. Lactobacillus species identification by amplified ribosomal 16S-23S rRNA restriction fragment length polymorphism analysis. Benef. Microbes 5:471-481.

Scott, R. 2002. Fabricación de Queso. 2nd ed. Editora Acribia S. A., Zaragoza, Spain.

Silvetti, T., S. Morandi, and M. Brasca. 2014. Biopreservation potential of Enterococcus faecalis isolated from Italian traditional raw milk cheeses. CyTA J. Food 12:210-217.

Souza, C. F. V., T. D. Rosa, and M. A. Z. Ayub. 2003. Changes in microbiological and physicochemical characteristics of Serrano cheese during manufacturing and ripening. Braz. J. Microbiol. $34: 260-266$.

Stamford, T. L. M., C. G. M. Silva, R. A. Mota, and A. Cunha Neto. 2006. Enterotoxidade de Staphylococcus spp. isolados de leite in natura. Ciênc. Tecnol. Aliment. 26:41-45.

Suhren, G., and H. G. Walte. 2000. First experiences with automatic flow cytometric determination of total bacteria count in raw milk. Pages 36-48 in Bulletin of the International Dairy Federation (IDF). No. 358 .

Terzic-Vidojevic, A., M. Tolinacki, M. Nikolic, J. Lozo, J. Bejovic, S. G. O. Gulahmadov, A. A. Kuliev, M. Dalgalarrondo, J.-M. Chob- 
ert, T. Haertlé, and L. Topisirovic. 2009. Phenotypic and genotypic characterization of lactic acid bacteria isolated from Azerbaijani traditional dairy products. Afr. J. Biotechnol. 8:2576-2588.

Torriani, S., G. E. Felis, and F. Dellaglio. 2001. Differentiation of Lactobacillus plantarum, L. pentosus, and L. paraplantarum by recA gene sequence analysis and multiplex PCR assay with recA genederived primers. Appl. Environ. Microbiol. 67:3450-3454.

Tournas, V., M. E. Stack, P. B. Mislivec, H. A. Koch, and R. Bandler. 2001. Yeasts, molds and mycotoxins. Chapter 18 in Bacteriological Analytical Manual Online. 8th ed. United States Food and Drug Administration, Rockville, MD.

Veljovic, K., A. Terzic-Vidojevic, M. Vukasinovic, I. Strahinic, J. Begovic, J. Lozo, M. Ostojic, and L. Topisirovic. 2007. Preliminary characterization of lactic acid bacteria isolated from Zlatar cheese. J. Appl. Microbiol. 103:2142-2152.

Ward, L. J. H., and M. J. Timmins. 1999. Differentiation of Lactobacillus casei, Lactobacillus paracasei and Lactobacillus rhamnosus by polymerase chain reaction. Lett. Appl. Microbiol. 29:90-92.
Wattiaux, M. A. 2012. Composição do leite e seu valor nutricional Essenciais em Gado de Leite (19), 73-76. Instituto Babcock para Pesquisa e Desenvolvimento da Pecuária Leiteira Internacional, University of Wisconsin-Madison. Accessed Dec. 5, 2014. http:// babcock.wisc.edu/sites/default/files/de/pt/de_19.pt.pdf.

WHO (World Health Organization). 2011a. Guidelines for drinkingwater quality. 4th ed. Accessed Dec. 02, 2014. http://www.who. int/water_sanitation_health/publications/2011/dwq_chapters/ en/index.html.

WHO (World Health Organization). 2011b. Hardness in drinking water. Background document for development of WHO Guidelines for drinking-water quality. Accessed Dec. 2, 2014. http://www. who.int/water_sanitation_health/dwq/chemicals/hardness.pdf.

Zahedi, F., M. H. Nasrabadi, M. T. Ebrahimi, M. Shabani, and H. Aboutalebi. 2011. Study the effect of Lactobacillus brevis isolated from Iranian traditional cheese on cutaneous wound healing in male rats on days 3 and 14. Razi J. Med. Sci. 18:16-23. 